\title{
A variety of reading disability associated with right hemisphere lesions
}

\author{
M. KINSBOURNE AND ELIZABETH K. WARRINGTON
}

From the National Hospital, Queen Square, London

Dyslexia, the apparently selective impairment in the ability to read words, or even individual letters, has been repeatedly described in association with left (major) hemisphere lesions. Verbal dyslexia, affecting the reading of words but not of isolated letters, may be characterized by paralexic errors (misreading of words). The paralexias may accompany similar (paraphasic) errors in spoken speech, and be secondary to a more general disorder of language function. They may occur in the 'parietal dyslexia' of Herrmann and Pötzl (1926) described as involving 'the frequent intrusion of incorrect words or word fragments in place of the ones actually in the text'. Patients with 'spelling dyslexia' in the absence of aphasia (Wolpert, 1924), who can only read words letter by letter because of a pathological limitation of their ability to perceive forms simultaneously, which prejudices the simultaneous perception of the whole word (Kinsbourne and Warrington, 1962a), make paralexic errors if they try to maintain normal reading speed. In contrast, patients with right-sided (minor hemisphere) damage, though sometimes liable to lose their place on the printed line (Paterson and Zangwill, 1944), have not been reported to show verbal dyslexia.

Below are described six right-handed patients with acquired right hemisphere lesions who suffered from reading disability. The paralexic errors were of a very characteristic, consistent, and hitherto undescribed type. They could be reproduced experimentally in a predictable fashion under the controlled conditions of tachistoscopic presentation of written material.

\section{CASE REPORTS}

CASE 1 M.S. (H.N. 95999), a right-handed woman aged 42, was admitted under the care of Dr. E. A. Carmichael 10 days after the sudden onset of left-sided spastic hemiparesis. On examination she also showed left-sided visual and tactile inattention, and impaired two-point discrimination, joint position sense, and stereognosis on the left. The left visual half field was normal when tested by single stimulation. There was mild neglect of the left side of space, as shown by testing her ability to bisect a line, count scattered objects, and describe pictures. She had mild difficulty in copying patterns. There was no evidence of aphasia. Testing on the W.A. intelligence scale showed that there had been no generalized intellectual deterioration. Optokinetic nystagmus was most marked on looking to the right. A right carotid arteriogram showed complete occlusion of the internal carotid artery at its origin.

CASE 2 M.R. (H.N. 95213), a right-handed man aged 65, was admitted under the care of Dr. D. Williams, having suffered gradual weakening of the left arm and leg over the last three months. On examination there was leftsided spastic hemiparesis, sensory loss, and visual inattention. The left visual half-field was normal when tested by single stimulation. Mild neglect of the left side of space became apparent in the counting of scattered objects, the description of pictures, and the copying of patterns. There was topographical loss. There was no aphasia. Testing on the W.A. intelligence scale showed minimal generalized intellectual deterioration. Signs of raised intracranial pressure became evident and ventriculography showed a right parietotemporal space-occupying lesion. Exploration through a temporal burr hole revealed a tumour shown at necropsy (four weeks after admission) to be secondary to carcinoma of the right upper bronchus.

CASE 3 A.H.B. (H.N. 2622), a right-handed man aged 59, was admitted under the care of Dr. R. W. Gilliatt, with essential hypertension and having suffered a left-sided stroke one year earlier. On examination there was a mild residual left spastic hemiparesis, complete left maculasplitting homonymous hemianopia (of which he was unaware), and bilateral deficit in two-point discrimination. He gave evidence of neglect of the left side of space when bisecting a line, counting scattered objects, and describing pictures. His constructional skill was handicapped by neglect of the left. There was no aphasia. Testing on the W.A. intelligence scale showed moderate generalized intellectual deterioration. Optokinetic nystagmus was most marked in looking to the right. A lumbar air-encephalogram showed dilatation of the right lateral ventricle and possibly also of the left.

CASE 4 F.B. (H.N. A2497), a right-handed man aged 62, was admitted under the care of Dr. J. Marshall after the sudden onset of left-sided weakness. On examination 
there was left spastic hemiplegia, complete left-sided sensory loss, and complete left macula-splitting homonymous hemianopia. He was unaware of these disabilities. He kept his gaze to the right, and appeared to attend only to the right-hand side of any object or array put before him. There was severe constructional disability; there was no aphasia. Testing on the W.A. intelligence scale showed only minimal intellectual deterioration in a man with a superior premorbid intelligence. A right carotid angiogram showed complete occlusion of the internal carotid artery at its origin.

CASE 5 R.W. (H.N. 92357), a right-handed man aged 49, was admitted under the care of Dr. J. Marshall two days after the sudden onset of a left-sided paralysis. On examination there was left spastic hemiparesis and sensory deficit, as well as complete left macula-splitting homonymous hemianopia, of which he was unaware. He initially denied ownership of his left arm. There was severe neglect of the left side of space, and he attended preferentially only to the extreme right of any object or array. His constructional abilities were severely impaired by unilateral neglect of space. There was no aphasia. Optokinetic nystagmus was most marked on looking to the right. A right carotid angiogram showed a spaceoccupying lesion in the right parieto-temporal area, where biopsy yielded infarcted brain tissue. At the time of this study, testing on the W.A. intelligence scale confirmed minimal generalized intellectual deterioration.

CASE 6 F.H. (H.N. 92519), a right-handed man aged 49, was admitted under the care of Dr. D. Brinton with a history of right frontal headaches, left-sided paralysis, and generalized epileptic seizures. On examination he had complete left macula-splitting homonymous hemianopia (of which he was unaware) and his eyes tended to swing conjugately to the right. There was left spastic hemiparesis and hemi-anaesthesia as well as a milder sensory deficit on the right. He neglected the left side of the body and of space, and he could, with difficulty, be induced to attend other than to the extreme right of any object or array put before him. There was constructional disability, but no aphasia. When tested on the intelligence scale he produced evidence of mild generalized intellectual deterioration. Optokinetic nystagmus was most marked on looking to the right. A right carotid angiogram was negative, ventriculography showed dilatation of both lateral ventricles, and right posterior parietal biopsy revealed granulomatous infiltration of the brain tissue.

The chinical findings in this group of patients are summarized in Table I

\section{THE READING DISABILITY}

Reading disability was not a presenting complaint in any case. On questioning, Cases 4, 5, and 6 admitted difficulty in the comprehension of a connected passage but not in the reading of individual words. On testing, isolated letters were at all times correctly read but isolated words, as well as words in a connected passage, were frequently misread. Examples of paralexic errors made in reading aloud from a standard word list (Schonell and Schonell, 1950) and a standard passage ('The King of the Golden River', Ruskin, adapted by Burt, 1923) are given in Table II.

All the paralexic errors, of which the above are examples, involved the beginnings of words. The last few letters of every word were correctly read; the ones preceding, forming the beginning of the word, were replaced by a substitute group. The substituting letters were always such as to change the whole into another word and never into a neologism. The new word would not necessarily resemble the one in the text either in its meaning or in the general configuration of the substituting and

\section{TABLE I}

SUMMARY OF FINDINGS IN PRESENT SERIES

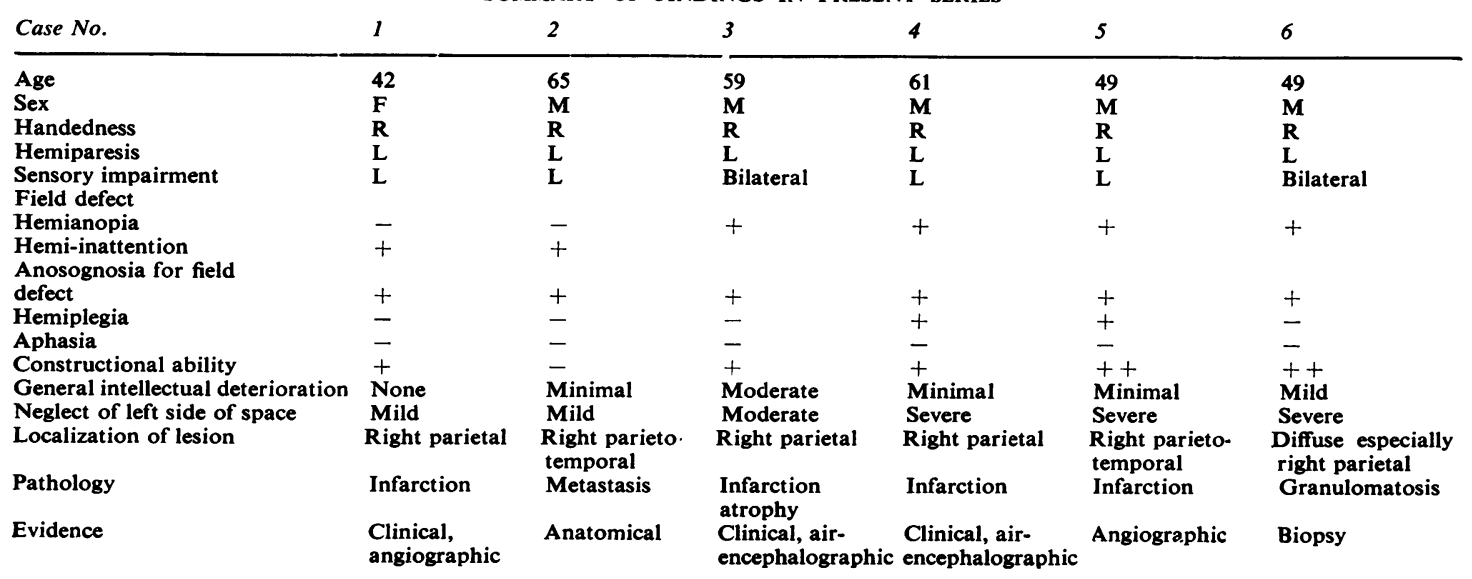


TABLE II

EXAMPLES OF ERRORS IN READING

\begin{tabular}{|c|c|c|c|c|c|}
\hline Case No. & 1 & 2 & & 3 & \\
\hline $\begin{array}{l}\text { level } \\
\text { peeping } \\
\text { shouldered } \\
\text { eight } \\
\text { touch } \\
\text { acquire } \\
\text { chronicles } \\
\text { our } \\
\text { wine } \\
\text { toffee }\end{array}$ & $\begin{array}{l}\text { novel } \\
\text { looking } \\
\text { ordered } \\
\text { tight } \\
\text { reach } \\
\text { require } \\
\text { articles } \\
\text { your } \\
\text { mine } \\
\text { coffee }\end{array}$ & $\begin{array}{l}\text { should } \\
\text { floating } \\
\text { ceiling } \\
\text { everyone } \\
\text { enterprise } \\
\text { message } \\
\text { light } \\
\text { people } \\
\text { controlling }\end{array}$ & $\begin{array}{l}\text { would } \\
\text { fighting } \\
\text { coiling } \\
\text { anyone } \\
\text { surprise } \\
\text { passage } \\
\text { sight } \\
\text { purple } \\
\text { carolling }\end{array}$ & $\begin{array}{l}\text { sit } \\
\text { milk } \\
\text { seige } \\
\text { postage } \\
\text { soloist } \\
\text { nourished } \\
\text { plausible } \\
\text { preferential } \\
\text { enigma } \\
\text { diseased }\end{array}$ & $\begin{array}{l}\text { bit } \\
\text { yolk } \\
\text { verge } \\
\text { hostage } \\
\text { methodist } \\
\text { flourished } \\
\text { inaudible } \\
\text { deferential } \\
\text { stigma } \\
\text { decreased }\end{array}$ \\
\hline Case No. & 4 & 5 & & 6 & \\
\hline $\begin{array}{l}\text { bun } \\
\text { book } \\
\text { milk } \\
\text { light } \\
\text { gnome } \\
\text { imagine } \\
\text { fascinate } \\
\text { fictitious } \\
\text { knowledge } \\
\text { statistics }\end{array}$ & $\begin{array}{l}\text { sun } \\
\text { look } \\
\text { chalk } \\
\text { night } \\
\text { income } \\
\text { engine } \\
\text { obstinate } \\
\text { anxious } \\
\text { pledge } \\
\text { acoustics }\end{array}$ & $\begin{array}{l}\text { bed } \\
\text { the } \\
\text { ran } \\
\text { geography } \\
\text { matchless } \\
\text { encumber } \\
\text { sarcastic } \\
\text { Peter } \\
\text { responsibility } \\
\text { reluctant }\end{array}$ & $\begin{array}{l}\text { red } \\
\text { be } \\
\text { an } \\
\text { autobiography } \\
\text { stretchless } \\
\text { cucumber } \\
\text { elastic } \\
\text { better } \\
\text { ability } \\
\text { expectant }\end{array}$ & $\begin{array}{l}\text { egg } \\
\text { train } \\
\text { people } \\
\text { shepherd } \\
\text { postage } \\
\text { susceptible } \\
\text { switch } \\
\text { advising } \\
\text { back } \\
\text { again }\end{array}$ & $\begin{array}{l}\text { beg } \\
\text { gain } \\
\text { saddle } \\
\text { beard } \\
\text { barge } \\
\text { eagle } \\
\text { watch } \\
\text { losing } \\
\text { pack } \\
\text { gain }\end{array}$ \\
\hline
\end{tabular}

In each case the right hand column gives the word as read by the patient. The letters that were correctly read are in italics.

substituted letters. The new word would not necessarily be of the same length as the one in the text though there was a tendency for length of substituting words to increase with the length of word in the text. Very occasionally, when the letter group at the end, correctly perceived, in itself amounted to a complete word, this was read out without addition. Single numbers were correctly read; of number groups, only the ones most to the right were read. The rest were omitted. No substitution of numbers was observed.

Scanning of the printed line was defective in Cases 4, 5, and 6, on account of a tendency always to attend first to the word or words of the extreme right of each line. This resulted in many words towards the left of the text being overlooked altogether. In Case 3 it was normal except for an occasional mild difficulty in finding the beginning of each line and omission of words at the extreme left. In Cases 1 and 2 it was entirely normal; in Case 1 an eye movement recording performed during reading showed the normal regular succession of saccadic jump and fixation pause.

Vertical reading of the standard text was tested by rotating the printed page through $90^{\circ}$, so that the printed line ran from above downwards. Under these conditions paralexic errors nearly completely disappeared. The few that occurred were no longer limited to the beginning of the affected word.

Comprehension of the standard passage was defective in all cases. As tested on Burt's comprehension tests, success in comprehension was found to be dictated not so much by the complexity of the passage as by whether any of the key words for comprehension happened to be among those which were misread. Any word that was misread was correspondingly misunderstood.

Awareness of reading disability was incomplete in all cases. No patient was aware of the fact that he misread individual words. Nor, during the reading process, was there any noticeable hesitation over the misread words. All six patients claimed to have read individual words correctly.

The relative severity of the reading disability as measured by the frequency of paralexic errors, and correspondingly by the degree of impairment of reading comprehension, was great in Cases 4,5 , and 6. The defect was moderate in Case 3 and mild in Cases 1 and 2.

\section{TACHISTOSCOPIC STUDY}

APPARATUS A Dodge type tachistoscope with a variable exposure setting ( 2 to $1,600 \mathrm{~m} . \mathrm{sec}$.) was used. The exposure field and background were of equal brightness ( $2 \mathrm{ft}$. lamberts) and subtended $14 \times 9^{\circ}$ of visual angle. The apparatus is described in detail by Kinsbourne and Warrington (1962b).

TEST MATERIAL Black capital letters, each subtending one half of a degree of visual angle when viewed through the tachistoscope, were printed on white cards, to the right of the centre. The word fragments were presented in two ways: just right of the fixation point and near the right border of the tachistoscopic screen $\left(3^{\circ}\right.$ to $6^{\circ}$ to the right of the fixation point). These followed each other in random sequence. 


$\begin{array}{lc}\text { Whole Words } & \text { Word Fragments } \\ \text { SINGING } & \text { GING } \\ \text { EDUCATION } & \text { TION } \\ \text { PLUMBER } & \text { MBER } \\ \text { SADDLE } & \text { DDLE } \\ \text { RETAIN } & \text { TAIN } \\ \text { DISPATCH } & \text { ATCH } \\ \text { NAVIGATOR } & \text { ATOR } \\ \text { IRRITATE } & \text { TATE } \\ \text { FOOLISH } & \text { LISH }\end{array}$

PROCEDURE The patient, after he had become accustomed to the light used, was asked to fixate a small central mark in the background field. Before each exposure he was warned that a group of letters would appear. He was then asked to report what he saw. The subject was not told that the letters would necessarily constitute a word nor was he told whether he had reported correctly. The exposure times were such as to ensure that the letters would be clearly visible in every case. Exposure times used were as follows:-

For Case 1500 m.sec., Case 250 m.sec., Case 3500 m.sec., Case 4800 m.sec., Case 5160 m.sec., Case 6 $500 \mathrm{~m} . \mathrm{sec}$.

RESULTS The patients' responses are given in Table III. It is apparent that on tachistoscopic presentation of words under the stated conditions paralexic errors were frequently made. These were of the same type as those found on clinical testing. Where letter groups not amounting to words were exposed, the patients reported seeing words of which objectively visible letters formed the ends. In less than half the misreadings the four letters actually presented were correctly read but incorporated into a larger word, of which they formed the end. In more than half the misreadings there was also substitution involving the one or two letters most to the left of the letter group presented. Letter fragments not amounting to words were rarely reported. The type of misreading was the same in whichever of the two positions the word fragment was presented.

\section{COLLATERAL STUDY}

Under the same conditions of tachistoscopic exposure, the series of incomplete geometrical figures used by Warrington (1962) was presented in the right half field in such a way that in each case the incomplete side of the figure just overlapped the mid-line. The patient was warned before each exposure; he was then asked to report what he saw.

RESULTS The six dyslexic patients reported complete figures as follows:

Case $180 \%$ of exposures, Case $2100 \%$, Case 3 $70 \%$, Case $460 \%$, Case $580 \%$, and Case $6100 \%$.

It is apparent that the dyslexic patients showed a strong tendency to 'complete' incomplete figures under the stated conditions.

\section{DISCUSSION}

The frequent incidence of paralexic errors and consequent impairment of comprehension gave rise to considerable reading disability in the cases reported here. The predominant type of paralexic error differed from that made by normal people ('proof readers' error'), illiterates, or young children (Monroe, 1928; Hildreth, 1932). This type of mis-

TABLE III

TACHISTOSCOPIC PRESENTATION OF WORDS AND LETTER GROUPS

\begin{tabular}{|c|c|c|c|c|c|c|}
\hline Case No. & $I$ & 2 & 3 & 4 & 5 & 6 \\
\hline $\begin{array}{l}\text { Whole Words } \\
\text { Singing } \\
\text { Education } \\
\text { Plumber } \\
\text { Saddle } \\
\text { Detain } \\
\text { Dispatch } \\
\text { Navigator } \\
\text { Irritate } \\
\text { Foolish }\end{array}$ & $\begin{array}{l}\text { ng } \\
\text { tion } \\
\text { under } \\
\text { table } \\
\text { rain } \\
\text { catch } \\
\text { indicator } \\
\text { date } \\
\text { Welsh }\end{array}$ & $\begin{array}{l}+ \\
+ \\
+ \\
+ \\
\text { curtain } \\
+ \\
+ \\
\text { pirate } \\
+\end{array}$ & $\begin{array}{l}\text { ringing } \\
+ \\
\text { plunger } \\
+ \\
\text { Britain } \\
+ \\
\text { refrigerator } \\
\text { estimate } \\
\text { Polish }\end{array}$ & $\begin{array}{l}+ \\
\text { publication } \\
\text { amber } \\
\text { uncle } \\
\text { obtain } \\
\text { patch } \\
\text { alligator } \\
\text { magnate } \\
\text { Polish }\end{array}$ & $\begin{array}{l}\text { Not tested } \\
\text { extrication } \\
\text { slumber } \\
\text { Not tested } \\
\text { Not tested } \\
\text { Not tested } \\
\text { narrator } \\
\text { Not tested } \\
\text { Not tested }\end{array}$ & $\begin{array}{l}\text { something } \\
\text { intimidation } \\
\text { amber } \\
\text { Not tested } \\
\text { Not tested } \\
\text { Not tested } \\
\text { elevator } \\
\text { Not tested } \\
\text { Not tested }\end{array}$ \\
\hline $\begin{array}{l}\text { Word Fragments } \\
\text { ging } \\
\text { tion } \\
\text { mber } \\
\text { ddle } \\
\text { atch } \\
\text { ator } \\
\text { lish } \\
\text { tate } \\
\text { tain }\end{array}$ & $\begin{array}{l}\text { going } \\
\text { on } \\
\text { er } \\
\text { stole } \\
\text { rich } \\
\text { actor } \\
\text { sh } \\
\text { date } \\
\text { rain }\end{array}$ & $\begin{array}{l}\text { coming } \\
\text { ton } \\
\text { number } \\
\text { middle } \\
\text { match } \\
\text { decorator } \\
\text { fish } \\
\text { mate } \\
\text { main }\end{array}$ & $\begin{array}{l}\text { casing } \\
\text { iron } \\
\text { member } \\
\text { textile } \\
\text { hatch } \\
\text { senator } \\
\text { English } \\
\text { tate } \\
\text { Spain }\end{array}$ & $\begin{array}{l}\text { song } \\
\text { position } \\
\text { amber } \\
\text { candle } \\
\text { each } \\
\text { agitator } \\
\text { churlish } \\
\text { magnate } \\
\text { join }\end{array}$ & $\begin{array}{l}\text { Not tested } \\
\text { dictation } \\
\text { Humber } \\
\text { Not tested } \\
\text { Not tested } \\
\text { alligator } \\
\text { Not tested } \\
\text { Not tested } \\
\text { Not tested }\end{array}$ & $\begin{array}{l}\text { Not tested } \\
\text { two ton } \\
\text { number } \\
\text { Not tested } \\
\text { Not tested } \\
\text { navigator } \\
\text { Not tested } \\
\text { Not tested } \\
\text { Not tested }\end{array}$ \\
\hline
\end{tabular}

The letters read correctly are in italics. $\quad+=$ word read correctly. 
reading has not previously been quoted in case reports of verbal dyslexia.

In normal reading words are thought to be perceived not letter by letter but on the basis of a few 'determining' letters, especially at the beginning of a word (Goldscheider and Müller, 1893) or by the total word form (Erdmann and Dodge, 1898) or both (Vernon, 1929). Where a part of a word is misread this might be any part (Erdmann and Dodge, 1898); on tachistoscopic presentation 'considerably the greatest number of errors occurred in the middle of the word' (Vernon, 1929). A predominance of errors limited to the beginning of words has not been reported in normal subjects nor is it a feature of dysphasic dyslexia (Weisenburg and McBride, 1935), 'spelling dyslexia' (Wolpert, 1924), or 'parietal' dyslexia (Herrmann and Pötzl, 1926). It is not quoted as an effect of left homonymous hemianopia as such (Rémond, Lesèvre, and Gabersek, 1957) nor of disordered eye movements (Altrocchi and Menkes, 1960). When difficulties in reading have resulted from minor hemisphere lesions (Kleist, 1934; Paterson and Zangwill, 1944) paralexic errors have not been reported as a feature. The present cases are the first examples of right hemisphere disease in which paralexic errors have been reported in the absence of a sinistral trait.

As is to be expected in minor hemisphere disease, the reading disability was not on an aphasic basis. Evidence of any disorder in the language sphere was absent. In the absence of dysphasia and dysgraphia, it becomes necessary to examine the perceptual aspects of reading in these cases.

The process of reading is characterized by the orderly succession of a saccadic jump and a fixation pause lasting 20 to 50 and $500 \mathrm{~m} . \mathrm{sec}$. respectively. In reading a line about $4 \frac{1}{2}$ inches long, a skilled reader will make about six fixation pauses (Neil, Redwood, and Schweitzer, 1949). During each fixation pause some 12 to 15 letters are read, and fixation falls almost exclusively on words rather than on the gaps between them 'and probably almost always roughly on the middle of the word' (Erdmann and Dodge, 1898). In so far as this normal process still occurred in the patients of this study, each fixation was likely to result in roughly half of the fixated word falling into the normal and half into the affected (hemianopic or hemiinattentive) field. The more clearly perceived end part of the word might then determine the reported version, which would be inaccurate only as regards the beginning of the word.

That this is not the complete explanation is shown by the tachistoscopic study. Letter groups to the right of the fixation point were, at least in part, correctly reported. But the patients amplified these letter groups into words of which they formed the endings. Other patients with left hemianopia, when tested tachiscopically, have been found to report the letter groups correctly and without addition. In other words, the six patients of this study behaved differently from other patients in that they 'completed' the letters that they perceived to form a word.

However, the misreadings were not confined to those letters that fell into the impaired visual field. Even when by tachistoscopic presentation it was ensured that the whole word fell into the intact field 'word completion' still occurred. Faulty fixation by the patients cannot account for this, as the same happened whether the word was presented just to the right of the fixation point or further to the right near the limit of the tachistoscopic screen and when these two forms of presentation were randomly intermingled. It must be concluded that the reading disability in these cases was determined by a peculiarity of visual perception of written material. Attention was given to the right-hand side of the word or letter group, whether presented by tachistoscope or glimpsed during a fixation pause in reading. The letters to the right were noted and completed 'backwards' (to the left) into a whole word.

The choice of word need not depend on context and when there is substitution it need not respect the contour of the substituted word fragment. The reported word was determined only by that part correctly perceived by the patient and by the extent of the patient's vocabulary. But there was a tendency also to report a longer word when the one in the text was long than when it was short. This raised the possibility that in some rudimentary manner the total word length was perceived.

If due to preferential perception of the right extremity of the printed line as suggested here, the typical backward completed paralexias should not occur in vertical reading; and this was borne out when the patients were required to read the standard text rotated through $90^{\circ}$. Any errors made in this unfamiliar task were not backward completing but of various types. It would also be expected that patients with comparable lesions whose native language (whether Hebrew or Arabic) is read from right to left would make errors limited to the ends of words.

Can left hemisphere lesions give rise to an analogous condition in which paralexic errors predominantly affect the right (end) part of words? Evidence is accumulating and will be presented in due course that such patients with 'forwardcompleting' reading disability exist and may be studied clinically and tachistoscopically in the way outlined here. These patients are reminiscent of 
the patient of Warrington and Zangwill (1957) who made errors in reading mainly affecting the ends of words. These errors, as the authors pointed out, were associated with defective eye movements towards the hemianopic side of the visual field in a patient unaware of his field defect. But in view of present results it seems likely that in this case, too, there was an abnormal distribution of visual attention here favouring the right rather than the left side of space.

In the six patients of the present study the unusual distribution of visual attention so as to favour the right side of the printed page had its counterpart in some evidence of neglect of the left side of space. In Cases 4, 5, and 6 this neglect was gross and associated with anosognosia for hemiplegia. All four patients who had hemianopia were unaware of this.

The association of the reading disability with an altered attitude to visual space and its contents suggests that there might be a tendency to 'complete' visual forms other than letter groups towards the 'neglected' side of space. The collateral tachistoscopic analysis of the perception of geometrical figures incomplete to the left gave the expected result. A high proportion of 'complete' responses was given by the patients but only very few by the controls. As in the series reported by Warrington (1962) the tendency towards completion of incomplete figures was strongly associated with unawareness of field defect. It is therefore likely that word-completion is an example of the completion of visual forms that may occur in hemianopia (Poppelreuter, 1917) and is indicative of parietal lobe disease (Warrington, 1962). The reading disability described here is determined by a pathological alteration in perceptual processes, which, under suitable conditions, can be shown to extend to the perception of visual forms other than letter groups. It is indicative of an abnormal distribution of visual attention. As for its localizing significance, in so far as unilateral neglect of space is indicative of a lesion of the contralateral parietal lobe (Critchley, 1953), the backward word-completing tendency, regarded as a sensitive index of the presence of neglect of the left side of space, is evidence of right parietal lobe disease.

\section{SUMMARY}

Six right-handed patients with right (minor) hemisphere disease and reading disability were shown to make paralexic errors predominantly limited to the beginning of the word. They made similar errors when confronted with letter groups or words presented tachistoscopically in the intact right half field. The reading disability, unassociated with dysphasia and dysgraphia, was the result of an abnormality of perception, not only of words but also of other visual forms. This abnormality was determined by an abnormal distribution of visual attention. Its presence provided evidence of neglect of the left side of space and thus of a right parietal lesion.

We wish to thank Drs. D. Brinton, E. A. Carmichael, R. W. Gilliatt, J. Marshall, and D. Williams for permission to report our studies on their patients; Dr. E. Slater for making facilities available for the experimental study; Professor O. L. Zangwill for helpful comment; and Mrs. E. King for help in testing the patients.

\section{REFERENCES}

Altrocchi, P. H., and Menkes, J. H. (1960). Brain, 83, 579.

Burt, C. (1923). Handbook of Tests. King, London.

Critchley, M. (1953). The Parietal Lobes. Arnold, London.

Erdmann, B., and Dodge, R. (1898). Psychologische Untersuchungen über das Lesen. Niemeyer, Halle.

Goldscheider, A., and Müller, R. F. (1893). Z. klin. Med., 23, 131.

Herrmann, G., and Pötzl, O. (1926). Uber die Agraphie. Karger. Berlin.

Hildreth, G. (1932). Child Develop., 3, 1.

Kinsbourne, M., and Warrington, E. K. (1962a). Brain, in the press. - (1962b), Ouart. J. exp. Psychol., in press.

Kleist, K. (1934). Gehirn-pathologie. Barth, Leipzig.

Monroe, M. (1928). Genet. Psychol. Monogr., 4, nos. 4 and 5.

Neil, E., Redwood, C. R. M., and Schweitzer, A. (1949). J. Physiol., $109,392$.

Paterson, A., and Zangwill, O. L. (1944). Brain, 67, 331.

Poppelreuter, W. (1917). Die psychischen Schädigungen durch Kopfschuss im Kriege 1914-16. Band I. Die Störungen der niederen und höheren Sehleistungen durch Verletzung des Okzipitalhirns. Voss, Leipzig.

Rémond, A., Lesèvre, N., and Gabersek, V. (1957). Rev. neurol., 96, 536.

Schonell, F. J., and Schonell, F. E. (1950). Diagnostic and Attainment Testing. Oliver and Boyd, Edinburgh and London.

Vernon, M. D. (1929). Spec. Rep. Ser. med. Res. Coun. (Lond.), No. 130, p. 5 . The errors made in reading.

Warrington, Elizabeth K. (1962). J. Neurol. Neurosurg. Psychiat. 25, 208.

-

Weisenburg, T., and McBride, K. E. (1935). Aphasia. Commonwealth Fund, New York.

Wolpert, I. (1924). Z. ges. Neurol. Psychiat., 93, 397. 